Thompson, L. et al. (2018). An exploration of the concept of community and its impact on participatory governance policy and service delivery in poor areas of Cape Town, South Africa.

\title{
An exploration of the concept of community and its impact on participatory governance policy and service delivery in poor areas of Cape Town, South Africa
}

\author{
Lisa Thompson, Chris Tapscott and Pamela Tsolekile De Wet
}

\begin{abstract}
The inclusion of citizen participation as a means to the equitable delivery of public services has distinguished South Africa's democratic development trajectory over the last 20 years. While equitable resource allocation remains high on the agenda of more recently democratised states, most of which have highly diverse and unequally resourced populations. Influencing the design of more inclusive participation is the notion of a universal citizenship that applies the concept of the equality of individuals to the needs, identities and sense of agency of citizens both between and within states. The liberal democratic theoretical conceptualisation of the individual centres on the notion of universal citizen, who is the recipient and embodiment of democracy through the rights bestowed through the democratic model. This conceptualisation has been criticised for its inability to deal with the imprecision of individual and collective political identities, especially as these evolve in newly democratic contexts. The construction of a single identity citizen living in communities imbued with homogenous characteristics is carried forward into the policy construction of participatory governance. This article explores and challenges the notion of the single identity citizen that belongs to one homogenous community that can be identified and drawn into formally constructed government spaces. The paper explores the construction of political and socio-economic identities and how notions of community are constructed by citizens, on the one hand, and government policies, on the other.
\end{abstract}

\section{Introduction}

Democratic development has become something of a clichéd phrase in terms of giving substance to the meaning of democracy and democratic rights in the global South. Many of the newly emerging democracies (as they are often called) claim to prioritise the provision of public and social services to all their citizens regardless of their socio-economic standing, ethnicity, creed or gender. Democratic development as a concept entails an implicit commitment to both equity and equality in terms of rights, more recently encompassing both political and socio-economic rights. Embedded in the conception of democratic development is the further commitment to ensuring that those who have been discriminated against can claim rights previously denied to them. The attainment of this objective remains a challenge for all countries, irrespective of their level of economic 
development, but it is especially problematic in newly democratised states with highly diverse and unequal populations.

Policies aimed at service delivery that are both equitable and also cognisant of historical inequalities include two somewhat antagonistic conceptions of citizenship. The use of citizenship in conjunction with participation in policy usually encompasses both the idea of a universal citizen, essentially an 'identity free' conceptual prototype that allows for collective characteristics to recede in the face of individual freedoms and equality before the law, as well as the acknowledgement of the need for redress in terms of the allocation of public goods and services to those who have been denied these on the basis of their collective identities. In policy terms, international best practice in local development and service delivery policy embodies prescriptions of efficiency, equity and, a corollary of the latter, citizen participation. In this formulation, community participation is included in policy design to ensure policies meet collective needs. There is, however, an implicit duality between the idea of participation based on the universal citizen devoid of any particular community identity, and the assumption in development policies that communities can be identified in relation to homogenous identities and needs. Chatterjee $(2004,4)$ refers to this duality as an 'inherent conflict',

... the opposition between the universal ideal of civil nationalism, based on individual freedoms and equal rights ... and the particular demands of cultural identity, which call for differential treatment of particular groups on grounds of vulnerability or backwardness or historical injustice, or indeed for numerous other reasons.

In terms of development, the notion of 'community' is integral to official thinking about the ways that states do or should interact with their citizens. Communities are seen as central to the dynamic of participatory government and in this discourse they are the targets of development intervention and their engagement is seen as essential to its validation. The concept of community, however, is generally treated as unproblematic and the collective to which this typically refers is seen by the state at all levels of the governing hierarchy (as well as by some donors) as largely homogenous and, to that extent, undifferentiated. Typically, as Agrawal and Gibson observe, communities are assumed to be groups of similarly endowed households (in terms of assets and income) who possess common characteristics of ethnicity, religion or language. 'Such homogeneity', they maintain ' $\ldots$ is assumed to further cooperative solutions, reduce hierarchical and conflictual interactions, and promote better resource management. Outside the community conflicts prevail, within, harmony reigns' (Agrawal and Gibson 1999, 634).

The idea that communities are homogenous, moreover, can be seen in the ways that state officials interact with different segments of the population and how, regardless of this diversity, they relentlessly pursue a Weberian symmetry in their delivery of public services. This practice, as many scholars have made explicit, has served to disadvantage the poor, minorities, the less educated and women, among other vulnerable segments of society (Kabeer 2005; Nyamu-Musembi 2002; Cornwall and Coelho 2007; Coelho and Von 
Lieres, 2010). All too often, their views are either not heard or are not acted upon by administrators, who tend to focus on the needs of the more vocal and influential members of a locality. The a-historical approach to identifying communities in order to roll-out democratic development policies becomes unstuck from the dualism between the individual and the disadvantaged collective, that is 'communities' that require identification and inclusion so as to ensure effective policy implementation occurs.

\section{Debunking the policy myth of community participation for democratic development}

In exploring the construction of community and the application of the concept to service delivery policies, this article shows how the notion of the single identity citizen that belongs to one homogenous community that can be identified and drawn into formally constructed government spaces creates a myth of democratic development that in policy processes works to the disadvantage of the most excluded. The paper explores community-based constructions of political and socio-economic identities and how these differing notions of community do not reconcile with the construction of community engagement as a policy directive. The inability of the official policy constructions of community participation to lead to effective development policy implementation to rectify the unequal resource allocation of public and social services is perhaps the most critical failure of policies aimed at democratic development. The paper draws on longitudinal case study research that has been undertaken over the last decade (2006-2016) in urban township areas in Cape Town. The case study material comprises both quantitative survey research as well as ethnographic and action-research approaches. A good deal of this research has been presented in detail in other publications (Thompson and Nleya 2010; Thompson and Tapscott, 2010; 2013; Thompson, Conradie and Tsolekile de Wet, 2014; Thompson, 2014; Thompson and Tsolekile de Wet 2017). For this reason the main aim of this article is not to duplicate the in-depth focus on research methodologies and processes and outcomes (although these will be referred to) but rather to present an overview of the common policy flaws revealed in the course of applying different research techniques to the investigation of the challenges of service delivery and the analytical implications thereof.

There is a broad literature on conceptual meanings of community, noticeable among scholars from the North (Cohen 1985; Crow and Allan 1994; Hoggett 1997 among others) and a countervailing literature, on how, in their failure to appreciate the complex dynamics of local social formations, participatory development programmes have been subject to elite capture or have failed to address the real needs of the poor (Cooke and Kothari 2001; Cornwall and Coelho 2007; Coelho and Von Lieres, 2010). Considerably less focus, however, has been directed to the ways in which state understandings of the concept of 'community', along with the administrative practices to which they give rise, routinely fail to encompass the diverse identities, agencies and needs of all their citizens, and in so doing reproduce both unequal relations of power in a society and patterns of poverty. State conceptions of community inclusion are not able to deal with the power relations already in place within the locales where socio-economic redress is to take place. By ignoring the traces of 'existing relationships of power' the state may unwittingly reproduce and reinforce 
these to the detriment of those who are the most resource deprived, and thus replicate patterns of inclusion and exclusion (Lefebvre 1991; Robins, Cornwall, and Von Lieres 2008, 1072).

Historical analyses of the emergence and changing the meaning of community emphasise the socio-economic and political construction of the sense of collective belonging inherent in the concept. This had originally to do with specific forms of livelihood interdependency as well as the need for the sacrifice of some individual freedom in the interests of collective security. In this regard, Bauman (2001) details the socio-economic evolution of the notion of community in the western context, and Freund (1998) alludes to a similar socio-economic trajectory of the ongoing reshaping of community identities throughout the colonial and post-colonial eras in Africa. In the African context, writers such as Amin (1976) and Mamdani (1996) amongst others, emphasise the ways in which the overlay of colonialism and patterns of economic migration have unravelled distinct notions of community, nationally and regionally. The current global political economy places additional tension on attempts to construct community as a stable, geographically definable entity. At the local level, both ethnographic as well as quantitative research on the impact of local government's basic services and social housing policies undertaken in some of Cape Town's poor urban areas underlines that identities, agencies and needs are unstable, and that geographical proximity may offer a sense of community to some collectives but very little to others (Thompson and Nleya 2010; Thompson, Conradie, and Tsolekile de Wet 2014). In fact, it is clear that collective identities are often constructed by leaders in order to access resources (Thompson and Tapscott, 2013). Collective identities are also multiple and shifting, and allegiances are not narrowly based on one determinant, such as ethnicity. This is often misrepresented in the popular press and lay understandings, where cultural, ethnic affiliations are somewhat simplistically understood as directly linked to political and community allegiances. Furthermore, those who are identified as representing different constructions of community have often more to do with power, patronage and clientelism, than with parity of rights and economic redress.

Recognising the difficulties inherent in theoretically grounding the concept, a number of writers have drawn attention to the ideological dimensions of community and community participation and argue that it is embedded in idealised notions of how society should be organised (Emmett 2000). Lacking a sound theoretical and conceptual framing, Emmett maintains, this state of affairs has given rise to a situation where states (and, it may be added, many international donor agencies, NGOs and academics) focus on the practical dimensions (techniques and methods) of community participation (2000, 502). Applied in this manner at the policy level, lacking conceptual rigour, the definition of community and community participation is left to the varied intuition, experience and commitment of officials at programme and project level. As a result, community involvement is largely doomed to be a messy and conflict-ridden undertaking, because balancing power relations in terms of representativeness will more often than not continue to dominate the discourse on effective and meaningful participation through the replication of existing patterns of inclusion and exclusion. 
Ideas about citizen participation and community-based development have been central to legislative and policy reform in post-Apartheid South Africa. This approach is driven principally by a commitment to promote a more egalitarian society, but also in part by a desire to develop a modern state embracing international best practice in good governance. In the discussion that follows, we examine how the notion of community is used, in legislation and policy, in processes of participation both in the delivery of services and in local level planning through the preparation of Integrated Development Plans (IDPs), and in the delivery of services and participatory social housing programmes in poor urban areas of Cape Town. ${ }^{1}$ We argue that participatory service delivery policies are premised on the understanding that homogenous communities exist and that irrespective of their different historical trajectories, social cohesion and socio-economic standing, they are able to mobilise and organise themselves to engage with the state to the benefit of all their members.

As a point of departure, it is necessary to provide a brief background to the factors that have influenced thinking about citizen participation and understandings of community in contemporary South Africa and of the way they have been incorporated into legislation and policy at all three levels of the governing hierarchy.

\section{The universal citizen and imagined communities}

In its efforts to overcome the racist and highly in-egalitarian legacy of Apartheid rule, the African National Congress, which assumed office in April 1994, committed to constructing a new social and political order which would assert the equality of all citizens and which would grant each a significant say in public decision-making. The quest for the universal notion of citizenship is evident in the 1996 South African Constitution, which not only prescribes 'a common South African citizenship' and asserts that all citizens are 'equally entitled to the rights, privileges and benefits of citizenship', but also maintains that they are 'equally subject to the duties and responsibilities of citizenship' (Section 3). In this context, it is assumed that the majority of the country's inhabitants not only have a clear understanding of the rights, privileges and benefits to which they are entitled, but that they also have equal ability to achieve these rights. As a legacy of Apartheid rule, South Africa remains a highly unequal society. The Gini-coefficient of equality, where 0 is perfectly equal, and 1 is perfectly equal, measures South Africa as fluctuating between 0.660 and 0.696, making South Africa one of the most unequal countries in the world (Bhorat 2015).

In the brave new world sketched by the country's first democratic government, considerable emphasis was placed on the need to work with communities and to afford citizens, particularly the poor, an opportunity to participate in decision-making. This was, at least in part, an attempt to overcome the destructive impact that Apartheid rule had had on the social fabric of those oppressed by white minority rule, that is the African, Coloured and Indian populations. During the Apartheid era, the concepts of 'community' and 
'community development' had extremely negative connotations, in large part because they formed part of the language of ethnic and racial segregation. The then Department of Community Development, in Orwellian fashion, played a key role in destroying long existing African, Coloured and Indian communities by forcibly removing them from areas designated for White habitation. For many African people this implied resettlement in distant rural areas (the so-called homelands) where they were frequently subjected to the patrimonial and authoritarian rule of traditional leaders, many of whom derived their authority from the Apartheid government. At the same time, Apartheid policies worked to inhibit associational life within the black population, fearing in its development the basis for mobilisation against white minority rule. The divide-and-rule policies of the Apartheid regime enforced racial and ethnic separation and effectively served to break down social cohesion and family life, as those living in the rural areas were forced into migratory labour for their survival (Southall 2013).

Whilst the struggle against Apartheid served to unite black people in a common cause and, to that extent, acted as a form of social glue, the depth of this cohesion was shallow and the focus of collective action was on political mobilisation rather than social organisation. The collective identities forged tended often to be dissipated as leaders were absorbed into the new government. As residential segregation ended, they also moved out of areas in which they had previously lived. The sense of collective identity was further eroded by the massive influx of rural people, previously restrained by Apartheid laws, into the urban areas. The need to mobilise the population to the task of building a new democratic state was thus a challenging one in the context of this social fragmentation and it was to the local level of government and the idea of community that the new government turned in pursuit of this goal.

Commencing with the 1996 Constitution, which stipulates that municipalities must provide 'democratic and accountable government for local communities' and must encourage 'the involvement of communities and community organisations in the matters of local government' (Section 152), a plethora of legislation has been enacted that explicitly charges different state structures with responsibility for engaging with (undefined) communities and the promotion of citizens' participation. Thus, the 1998 White Paper on Local Government committed municipalities 'to work together with local communities to find sustainable ways to meet their needs and improve the quality of their lives' (Section B). Implicit in this approach was the need for local government to actively promote the participation of their citizens, particularly those from marginalised sections of the community:

Municipalities must adopt inclusive approaches to fostering community participation, including strategies aimed at removing obstacles to, and actively encouraging, the participation of marginalised groups in the local community. (DCD Section 1.3)

The idea of community participation in local systems of governance was further evident in the Local Government Municipal Services Act of 2000, which exhorted municipalities to 
'establish appropriate mechanisms, processes and procedures to enable the local community to participate in the affairs of the municipality' (Section 17.2). According to the Act:

A municipality must develop a culture of municipal government that compliments formal representative government with a system of participatory governance, and must for this purpose ... encourage and create conditions for the local community to participate in the affairs of the municipality. (Section 16.1)

The commitment to community engagement is also to be seen at the sectoral level and in the delivery of public housing in particular. Thus the 1994 Housing White Paper committed the Government to 'a development process driven from within communities', which would promote 'the participation of affected communities in the planning and implementation of new developments' (Sections 4.4.4. and 4.5.1.). This perspective was also advanced in the 1997 National Housing Act which asserts that national, provincial and local spheres of government must 'consult meaningfully with individual and communities affected by housing development'(Section 2(1)). It is further evident in the 2008 Social Housing Act. The Act emphasises the need to 'consult with interested individuals, communities and financial institutions in all phases of social housing development' (Section 4.4.4.).

What is striking in a review of policy documents on local government is that the concept of community is used so fluidly to describe a wide array of ideas. Where legislation and policy produced in the late 1990 s spoke un-problematically of 'the community' or the 'local community' (RSA 1997), subsequent documents have broadened the usage of the term to cover a variety of categories. Thus the Local Government Municipal Systems Act of 2000, one of the very few documents to attempt a definition, refers to a 'local community' or 'community' as being:

... that body of persons comprising a) the residents of the municipality; b) the ratepayers of the municipality: c) any civic organisations and non-governmental, private sector or labour organisations or bodies which are involved in local affairs within the municipality: and d) visitors and other people residing outside the municipality who, because of their presence in the municipality, make use of services or facilities provided by the municipality, and includes, more specifically, the poor and other disadvantaged sections of such body of persons .... (Section 1)

From this definition, it is evident that a community may refer to a geographical agglomeration of people (the residents of a municipality), special interest groups (ratepayers, organised labour etc.), user groups (those from outside of a municipality making use of its facilities) and the poor. In other words, a community is pretty much whatever national policy-makers define it to be in any given context.

This problem is compounded by the fact that the delivery of key basic services such as housing, electricity and water is a concurrent responsibility of all three tiers of government 
and problems of coordination between them abound (PGWC 2011, 15). Although provincial and local government are constitutionally compelled to follow the broad directions of national government policy, the way in which they implement this is left to their own interpretation. In the case of Cape Town, which falls under the political control of the opposition Democratic Alliance at both municipal and provincial levels, problems of policy alignment are further constrained. In this context, possibilities exist for still further different conceptualisations of community. Thus, for example, in recent documents the provincial Department of Human Settlements avoids the use of the term 'community' in entirety, preferring to refer to those in need of housing as 'citizens' or 'stakeholders' (PGWC 2011). The City of Cape Town's Five Year Integrated Housing Plan 2011/20122016 similarly avoids the use of community and refers to 'households', 'residents' or 'groups of people'.

While this approach avoids the conceptual pitfalls that beset national policy, it does little to resolve the definitional challenges posed by national legislation. This is because the conceptual vagueness of 'community' aside, the administrative practicalities of involving citizens in the participatory process have also seldom been made explicit at any level. The research that this paper reflects upon suggests that the impact of this analytical vagueness becomes acute when local administrators attempt to implement policy. Here the tendency is to fall back on the idea a homogenised community projected in national legislation and policy, living in contiguous space, with a collective identity, a recognised leadership and common needs. While some social collectives fit this conceptual model, many do not. As a legacy of Apartheid, as indicated, many social groups remain deeply fractured and could be considered communities only in name. The histories of social mobilisation across society, furthermore, differ significantly from one locality to another. In some, such as those of African people who migrated in from the rural areas some 20 years ago and who now reside in the sprawling formal and informal settlements centred around Khayelitsha and Langa/Nyanga on the margins of metropolitan Cape Town, there is a strong tradition of community organisation, born out of the anti-Apartheid struggle, and residents are accustomed to electing representatives to street committees, ward committees and the like. As a result of these more established patterns of social organisation, local leaders are more closely linked to the areas they represent, although there are still problems associated with the legitimacy and responsiveness of political representatives, particularly in relation to ward councillors (Thompson and Nleya 2010; Piper and Nadvi 2010; Thompson, Conradie, and Tsolekile de Wet 2014). In areas where there has been little or no history of social mobilisation, conversely, there is frequently neither a sense of collective identity nor a recognised leadership with the legitimacy to speak on behalf of the collective. The section that follows provides some evidence of the ways that the conceptual vagueness of 'community' in development policy discourse has rendered the process of citizen participation as fraught. 


\section{Targeting the 'community' in policies: assumptions about participation in setting service delivery policy priorities}

The presumption by officials that all citizens in a municipality are equally capable of organising themselves towards a common cause around a legitimate leadership and that there is a tradition of voluntarism sufficient within them to sustain this, is illustrative of a superficial grasp of (or a disinterest in) the complex social dynamics that make up all communities, however defined and irrespective of their socio-economic character. The way in which community is officially imagined is evident in the rollout of Integrated Development Plan (IDP) participatory processes.

The establishment of mechanisms for the promotion of citizen participation is generally set as a precondition for the receipt of central government grants. Thus, in terms of the Municipal Systems Act of 2000, each newly elected council must, within a prescribed period, prepare and adopt an inclusive plan, which aligns the projects, programmes, budgets and other council resources with the sustainable development priorities of the community. In terms of the Act, the preparation of an IDP must include an extensive process of public consultation, both to determine local priorities and to promote a sense of citizen and community involvement in the running of the municipality. In terms of the prescripts of the Act, a municipality must allow for: (i) the local community to be consulted on its development needs and priorities and (ii) the local community to participate in the drafting of the IDP ... (Section 29.1). The soliciting of what is known as 'community buy-in' is a central component of this process (Mhone 2003).

In Cape Town, as elsewhere, IDP participatory processes are organised by councillors, in an approach intended to ensure that communities are consulted. This forms part of a structured process of calling and documenting meetings with the residents of different localities in the city. This process is intended to be comprehensive and yet survey data and key informant interviews in the poor and predominantly informal areas of Khayelitsha, Langa and Delft show that most residents are unaware or unfamiliar with IDP processes (Thompson and Nleya 2010; Thompson, 2014). It is also not clear who has participated in the consultation process, as focus group interviews show that few people have attended an IDP meeting called by councillors. The sense that engagement with a broad group of the residents will result in a better flow of communication on the identification and prioritisation of needs is not evident in the actual consultation process. Between 2011 and 2016, discussions with officials in the City of Cape Town (CoCT) associated with IDP participatory processes indicate that the priority lists of local development initiatives which councillors forward to the City are mostly 'unusable wish lists' that reflect individual rather than community concerns. Senior officials in the CoCT are aware of the compliance-based nature of the IDP process, and that due to the IDP consultative process taking place in politically demarcated municipal wards that correspond to local election constituencies, it is virtually impossible to get 'community' input, because even in areas where there are more self-defined forms of collective identification like Khayelitsha, Langa and Delft, these do not necessarily correspond with ward boundaries. This expresses very clearly the duality or conflict between universal individualism and collective self- 
identification which occurs in policy as mentioned by Chatterjee earlier in this paper. Democracy in practice can serve to undermine, rather than overcome, inequalities through a system based on notions of individual representation that must translate into a largely predefined collective (the ward in this case) that has little or no anchorage in forms of community self -identification.

Further difficulty with a homogenous policy conception of community is evidenced in the rollout of a variety of social housing schemes. In this instance, a municipality is obligated by the National Housing Code to work with the elected representatives of groups targeted for receipt of public housing through what are called beneficiary committees (2009, Part 3). In the format envisaged in the policy, the beneficiary committees (as the legitimate representatives of a community) should assist the municipality in the selection of beneficiaries for a given project. However, the different types of housing projects present different challenges in both identifying the most appropriate community-based partners and in selecting eligible beneficiaries in a fair and transparent manner.

Referring again to the research on social housing allocation and community participation, in the case of a project aimed at the in situ upgrading of an entire informal settlement (i.e. shacks are replaced with conventional housing), beneficiaries are more likely to know the individuals whom they elect to a committee and, hence, are more likely to accept the decisions taken on their behalf. However, in the case of Greenfield (referring to projects where houses are built from scratch, beneficiaries are relocated from shack areas) projects which draw potential beneficiaries from an entire municipality, the process of electing a representative beneficiary committee is especially challenging. This is because beneficiaries are not known to each other, they have no history of collaboration and trust levels between them are usually low. Despite these obvious distinctions, the process of community consultation advocated in the housing policy remains essentially the same for all projects (Tapscott and Thompson 2013). Here, engagement with an imagined community can actually do harm to the efficacy of the policy, as its putative leaders are expected to assist with the selection of beneficiaries, and may be asked to explain selection processes to their constituencies. However, as they lack a formal mandate from those they are supposed to represent, the decisions of these beneficiary committees are distrusted and this, in turn, leads to distrust of the entire process of participation.

Lacking clear directives on how to identify communities and community leaders, there is a tendency on the part of officials, eager to get housing projects off the ground, to engage with anyone who purports to speak on behalf of the potential beneficiaries. Such leaders, often elected by acclamation on the basis of a nomination at the first public meeting of beneficiaries, frequently pursue narrow and self-centred agendas. As Thornton and Mamphele point out,

... $(\mathrm{t})$ here is a difference ... between visibility and genuine political representation ... In what could be called take-me-to-your-leader syndrome ... well-meaning people ... end up 
establishing relationships with the most visible people who tend to be very articulate as spokespersons (mostly spokesmen) of 'their' people. (Thornton and Ramphela 1988, 32, emphasis in original)

Evidence of this syndrome emerged in the implementation of social housing in the Drakenstein municipality in the Western Cape, where a group of self-appointed community leaders negotiated with the local political leadership just prior to elections and were successful in ensuring that the beneficiary allocation system was altered in their favour. This self-same group of representatives excluded women leaders from their ranks, claiming they were 'noisy and troublesome, they make things more difficult'. The resultant mobilisation, politically timed just before local elections, led to a prioritisation of the more politically aligned informal residents group. As a result, other, equally desperate households who had been on the municipal housing waiting list for longer, but who lacked visibility, had to remain waiting (ACCEDE Beneficiary Committee Housing Report 2010). In such contexts, Bauman (2001) asserts that community 'claims' can become antithetical to the broader understandings of individual rights as these come to be competing. Kabeer (2005) and Nyamu-Musembi (2002) discuss the dilemma in the context of the global South, where constructions of community identity can, and indeed have, become deeply polarising. Echoing and adding to Chatterjee (2004), NyamuMusembi highlights that the dilemma is around crafting legal (and policy) frameworks that ' ... do not disregard the community context in which people are embedded, but at the same time do not legitimize a narrow definition of personhood based on status in hierarchical relationships' (Nyamu-Musembi 2002, 41). Nyamu-Musembi pinpoints the further dilemma of using the notion of the universal citizen, this definition of personhood valorises a mythical equality that preserves the status quo.

For policy-makers, the challenge is to get the balance right in engaging with citizens without embracing too simplistic an understanding of community, the more so in the context of a global development discourse that views participation as a key component of a modern democratic state. However, it needs to be highlighted that even in communities where there is a sense of social cohesion, socio-economic tensions and the competition for scarce resources remain a feature of daily life (Thompson, Conradie, and Tsolekile de Wet 2014). Even survey data on basic services collected over a longitudinal time frame illustrates the limited degree to which communities understood to have fairly high levels of social cohesion discuss important concerns with each other and also with their local councillor. Forms of collective representation and mobilisation have grown, as witnessed by survey data showing an increase in interaction with councillors between 2011 and 2013 in Khayelitsha, with $38 \%$ of residents having engaged collectively. Even so, in 2013, 69\% of residents still felt that 'people like me have no influence over what the government does' (Thompson, 2014). Survey data and ongoing action-research engagement with leaders of civil society organisations (CSOs) in Langa, Khayelitsha and Delft show that while even in areas where there are higher degrees of homogeneity due to cultural and ethnic affiliation, such fixed community identities do not necessarily translate into collective political identities and rights claims. 
Again, even in these areas with more community cohesion, public meetings may be regularly attended, but this does not necessarily lead to the lobbying of councillors or ward committees to address community 'needs' as these needs are not neatly coterminous with ward boundaries. As Thornton and Ramphela $(1988,38)$ put it,

Here again, the question of the collective finding 'voice' to articulate their demands through democratic processes is again confounded by the disjuncture between the idea of community and the practice, including the assumed action-based nature of communities, especially the poor. As Cooke and Kothari (2001) describe it, the tyranny of participatory governance falls to the poor. Participatory policy is then further confounded by the liberal assumption that the individual will have not just the inclination, but also the means to exercise his or her rights within any arbitrarily designed or constructed notion of community. The ward as the focus point for much of arbitrarily defined community engagement in development in South Africa is a prime case in point.

This leads the discussion back to the fraught question of who ultimately represents whom in the participatory spaces that government, especially at local level, created to ensure 'effective consultation and collaboration'. Research undertaken with smaller CSOs and local social movements who have less political patronage and connections, but who may more authentically represent the voices of the historically excluded, show fairly low rates of inclusion into government-initiated participatory spaces and processes, despite using the same repertoire of actions of larger, better connected and funded CSOs. Such repertoires of action include consultation, engagement and protest (Thompson and Nleya 2010). Protest is often due to the perceived failure of formal processes of citizen participation and the failure of development policies to meet the needs of the poor. ${ }^{2}$ Protest, we have shown elsewhere, is usually the last of the range of measures used to achieve collective goals. Among communities, the dominant service delivery issue is social and low-cost housing and the allocation thereof, followed by other basic service issues like water, sanitation and electricity provision. This remains perhaps one of the most critical areas where grievances around fairness and socio-economic redress occur, and where the messiness around defining community emerges the most starkly (Interviews, Sivukile Sonele and Community Justice Movement 2014-2015). Protest is more likely to occur when groups feel they are being excluded from spaces, that they are not being consulted or 'listened to' and that the criteria for choice with regard to allocations of services or resources to certain community groupings over others is not made clear. Local governments, on the other hand, within the spaces they create for engagement, often resort to consultation and information sharing rather than engagement and evaluation of contesting demands. Contested demands, especially from smaller groups and movements, are often dismissed as 'trouble-making' and illegal, and police action is frequently used to address protest that is defined as such. This cycle of government intolerance towards the frustration felt by residents who feel they are not being included in the conceptions of community that local government uses, cuts to the heart of the current problem of escalating protest action in South Africa. 
A good example of the above point is the case of protest action undertaken by the small scale, Langa-based local social movement, Sivukile Sonele. 3 Recent housing allocation participatory forums in Langa did not include all stakeholders, and housing project allocations were explained to a selected group of residents at series of purportedly 'public' meetings that were not widely advertised. Resistance to the allocations by residents who grouped to form Sivukile Sonele first took the form of requests to see the Mayor and later the Public Protector. After such efforts did not result in mutually meaningful engagement on key issues around housing allocation, the movement held a public meeting, declared illegal by CoCT, where the leaders were arrested and only released on condition that they would not organise such public gatherings again, pending further legal action by the City. Thereafter, further protests ensued, and the resultant police action and media exposure led to a meeting between the leaders of Sivukile Sonele and the Minister for Human Settlements. While the outcome of the housing allocation has remained largely unchanged, after the meeting with the minister charges against the Sivukile Sonele leader of public agitation were dropped and assurances given that the 'matter would be looked into' (Thompson and Tsolekile de Wet 2017).

The question of inclusion and exclusion of certain groups in the allocation process was clearly at issue, with the provincial Department of Human Settlements insisting that all 'legitimate' stakeholders had been consulted. The growth of Sivukile Sonele over the same period in response to allocation grievances shows clearly that at grassroots level many did not feel this was a reflection of what had transpired in terms of public participation. The grievances arose from a collective feeling of exclusion across a wide section of Langa residents. While these groupings may not have been identified by the housing project developers as beneficiaries, their perceptions of lack of consultation, transparency and accountability with regard to the housing allocation are a further indication of the problematic way in which 'çommunities' are identified to form part of participatory governance and development policies and processes, and how policies are communicated to 'interested and affected parties'. Sivukile Sonele has demanded to know the basis on which certain allocations to communities have been made, where clientelism is perceived on the part of residents. While the movement's allegations are ostensibly now recognised (only after protest action) their efforts to engage and be heard prior to the protest were completely unsuccessful. As Robins, Cornwall and Von Lieres 2008,1082 ) point out, 'It would seem that democracy works for elites who already speak the language of bureaucratic state power, but is less efficacious for the rank-and-file of the popular classes'. Those who do not speak this language, and who do not have party allegiances and/or political influence, are dismissed as unruly and illegitimate. For those groups who do not have political influence, it is not clear whether protest will make any difference to the way in which contesting demands and understandings of fairness of allocation are to be dealt with at local level. It is clear that the contestation is not just about who gets resources, but about how this is communicated and who and how the 
political leadership of designated communities are engaged, irrespective of whether or not they will be recipients of the service in question.

\section{Conclusion}

The common threads of the various longitudinal case study research findings used as examples in this paper highlight the dualities and tensions between the understandings of universal citizenry, on one hand, and the notion of a homogenous community, on the other, as a central concept in the official development discourse in South Africa. Ironically, the notion of the 'community' so central to Apartheid policy, and the ethnic fragmentation of the population, is still a fundamental feature of policies addressing inequalities at the local level. However, as this predominantly analytical discussion has attempted to underscore, beyond its rhetorical appeal, the ill-defined and undifferentiated term 'community' facilitates neither citizen participation nor the targeting of those most in need of state support. It also points to the fact that the needs of the poor are difficult to aggregate and the diversity and complexity of their different forms of social organisation need to be contextualised and factored into local development programmes. Finally, policies that target community participation require more specificity about what the intended outcomes of participation are. Without a clear understanding of what the policy outcomes could possibly be, there is always the possibility that stakeholders will expect to shape these in ways that might not be possible, or even desirable. Meaningful participation as both a concept and a process requires careful clarification for it to move beyond being a fuzzy 'feel good' phrase in terms of policy formulation.

This, then, is the challenge of ensuring that policy design does not rest on imagined communities that replicate power relations and patterns of clientelism. If consultation and participation are to rest on superficial constructions of collective cohesion, they run the risk of valorising the visible, invariably those with the knowledge and power to achieve such visibility. If instead, they rely too heavily on the image of the individual in community in the neo-liberal sense, collective interests may be underplayed and existing hierarchies of power replicated. A more detailed operational dimension to consulting with communities, and identification of community interests ought to be an initial point of redress, as well as an acknowledgement of the fact that communities are not stable entities but are constantly in flux. There needs to be recognition of the fact that identities that constitute different configurations of community are also shifting. Community, identity and space can articulate very differently in relation to different issues and at different points in time (Thornton and Ramphela 1988, 38; Lefebvre 1991). Communities are also the sites of many interests and conceptualisations of identity rather than one collective coherent harmonious vision, especially when it comes to the division of resources. This means that the design and rollout of policies needs to be reflexive in relation to balancing competing community interests, and power relations and more precise about what the outcomes of participation ought to be, especially with regard to the allocation of resources amongst the most needy. 


\section{Notes}

1. The research on which this article draws spans a 10-year-period. We acknowledge and thank the Ford Foundation and Vlaamse Inter-Universitaire Raad (VLIR) for funding the longitudinal research programme. Between 2006 and 2016, the research programme comprised of bi-annual quantitative surveys focusing on basic service delivery and governance issues in poor urban areas as well as ongoing ethnographic and action-based research with community groups and leaders in poor urban areas in Cape Town, predominantly, Khayeltisha, Langa and Delft.

2. Service delivery protest statistics to date show a rapid increase in protests, especially before elections. In 2014, there were 218 protests across the country, mostly in the five metropolitan areas (Civic Protest Barometer, 2015).

3. This section refers to research engagement and action-based capacitation fieldwork with Sivukile Sonele, a small social movement in Langa that, unlike other more successful movements such as the Social Justice Coalition in Khayelitsha, is currently unfunded. It is also entirely led and managed by community leaders and members. The activist-based research undertaken with Sivukile Sonele took place over the period 2014-2016. The nature of the capacitation/ action-based research involved information sharing and discussions on key policy and legal obligations of CoCT towards local communities with regard to service delivery, so as to provide the necessary technical policy knowledge to assist Sivukile Sonele in their engagements with the City. We thank the Ford Foundation for their funding support of the Sivukile research. See Thompson and Tsolekile de Wet (2017) for a more in-depth analysis of the movement.

\section{Disclosure statement}

No potential conflict of interest was reported by the authors.

\section{Funding}

This work was supported by Ford Foundation [01450184]. 


\section{References}

ACCEDE. 2010. The Role of Community Beneficiary Committees in Housing Allocation, contracted by the Western Cape Provincial Department of Housing, (2009-2010).

Agrawal, A., and C. Gibson. 1999. "Enchantment and Disenchantment: The Role of Community in Natural Resource Conservation.” World Development 27 (4): 629649.

Amin, S. 1976. Unequal Development. New York: Monthly Review Press.

Bauman, Z. 2001. Community: Seeking Safety in an Insecure World. Cambridge: Polity Press.

Bhorat, H. 2015. "Is South Africa the most unequal society in the world?" Mail and Guardian Online, September 30.

Chatterjee, P. 2004. The Politics of the Governed. New York: Columbia University Press.

Coelho, V. and Von Lieres, B. (eds). 2010. Mobilising for Democracy: Citizen Action and the Politics of Public Participation. London: Zed Books.

Cohen, A. 1985. The Symbolic Construction of Community. London: Tavistock.

Community Law Centre. 2015. Civic Protest Barometer. Belville: University of the Western Cape (UWC). Cooke, B., and U. Kothari, eds. 2001. Participation: The New Tyranny? London: Zed Books.

Cornwall, A., and V. Coelho, eds. 2007. Spaces for Change: The Politics of Citizen Participation in New Democratic Arenas. London: Zed Books.

Crow, G., and G. Allan. 1994. Community Life: An introduction to Local Social Relations. Hemel Hempstead: Harvester Wheatsheaf.

Emmett, T. 2000. "Beyond Community Participation? Alternative Routes to Civil Engagement and Development in South Africa." Development Southern Africa 17 (4): 501-518.

Freund, B. 1998. The Making of Contemporary Africa: The Development of African Society Since 180o. London: Palgrave MacMillan.

Hoggett, P., ed. 1997. Contested Communities: Experiences, Struggles, Policies. Bristol: Policy Press. Kabeer, N., ed. 2005. Inclusive Citizenship: Meanings and Expressions. London: Zed Books.

Lefebvre, H. 1991. The Production of Space. Blackwell: Oxford.

Mamdani, M. 1996. Citizen and the Subject: Contemporary Africa and the Legacy of Late Colonialism. Cape Town: David Phillip.

Mhone, G. 2003. "Democratisation, Economic Liberalisation and the Quest for Sustainable Development in South Africa." In Governance in the New South Africa: The Challenges of Globalisation, edited by G. Mhone and O. Edigheji, 1865. Cape Town: UCT Press.

Nyamu-Musembi, C. 2002. "An Actor Oriented Perspective on Human Rights.” IDS Bulletin 36 (1): 41-51.

Piper, L., and L. Nadvi. 2010. "Popular Mobilisation, Party Dominance and Participatory Governance in South Africa." In Citizenship and Social Movements: Perspectives from the Global South, edited by L. Thompson and C. Tapscott, 212-238. London: Zed Books. 
Provincial Government of the Western Cape. 2011. Department of Human Settlements, Annual

http://www.westerncape.gov.za/Text/2012/2/annual_report_2011_part1.pdf

Robins, S., A. Cornwall, and B. Von Lieres. 2008. "Rethinking Citizenship in the PostColony.” Third World Quarterly 29 (6): 1069-1086.

RSA. 1997. National Housing Act 107 of 1997. Cape Town: Government Gazette 18521.

Southall, R. 2013. Liberation Movements in Power: Party and State in Southern Africa. London: James Currey.

Thompson, L. 2014. "Agency and Action: Perceptions of Governance and Service Delivery in Poor Urban Areas in Cape Town." Politikon 41 (1): 39-58.

Thompson, L., I. Conradie, and P. Tsolekile de Wet. 2014. "Participatory Politics: Understanding Civil Society Organisations in Governance Networks in Khayelitsha." Politikon 41 (3): 387-402.

Thompson, L., and N. Nleya. 2010. "Passivity or Protest? Understanding the Dimensions of Mobilization on Rights to Services in Khayelitsha, Cape Town." In Mobilising for Democracy, edited by V. Coelho and B. Von Lieres, 232-242. London: Zed Books.

Thompson, L., and C. Tapscott. 2010. "Mobilisation and Social Movements in the South: The challenges of Inclusive Governance." In Citizenship and Social Movements, edited by L. Thompson, and C. Tapscott. London: Zed Books.

Thompson, L., and C. Tapscott. 2013. "Between Supply and Demand: The Limits to Participatory Development in South Africa." International Review of Administrative Science 79 (2): $368-385$.

Thompson, L., and P. Tsolekile de Wet. 2017. "Exploring Community Visibility and Legitimacy of Voice: The Case of Sivukile Sonele Social Movement in Langa, 20152016.” ACCEDE Working Paper No. 16 Bellville: ACCEDE, UWC.

Thornton, R., and M. Ramphela. 1988. "The Quest for Community." In South African Key Words: The Uses and Abuses of Political Concepts, edited by E. Boonzanier and J. S. Sharp. Cape Town: David Philip. 